\title{
Pengawasan Pengelolaan Lingkungan Dibidang Pertambangan Berdasarkan Undang-Undang No. 4 Tahun 2009 Tentang Pertambangan Mineral dan Batu Bara
}

\author{
Eren Arif Budiman ${ }^{1 *}$, Ahmad Arif Zulfikar ${ }^{2}$ \\ ${ }^{1,2}$ Magister of Law, Universitas Muhammadiyah Yogyakarta \\ Jl. Brawijaya, Geblagan, Tamantirto, Kec. Kasihan, Bantul, Daerah Istimewa Yogyakarta 55183 \\ *Correspondence email: erenbdmn@gmail.com; ahmadarifzulfikar1@gmail.com
}

\begin{abstract}
Abstrak. Permasalahan sengketa lingkungan yang mempengaruhi pada pengelolaan SDA salah satunya merupakan aktifitas pertambangan. Berlandaskan Undang- undang Nomor. 4 tahun 2009 mengenai Pertambangan Mineral serta Batubara mulai membuka alam terkini mengenai pandangan yuridis mengenai pengurusan pertambangan dari pandangan lingkungannya selain juga disinggung mengenai independensi pertambangan Indonesia. Kontribusi pemerintah dalam perumusan peraturan pengawasan pengurusan lingkungan wajib dimaksimalkan sebab sumber energi alam sungguh berarti peranannya lebih- lebih dalam rencana menaikkan pemasukan negeri lewat metode fiskal, pungutan serta untuk hasil yang nyata serta seimbang, dan proteksi dari musibah ekologis. Searah dengan independensi wilayah, pendelegasian dengan cara berangsur- angsur wewenang penguasa pusat pada penguasa wilayah dalam pengurusan pangkal energi alam dimaksudkan buat tingkatkan kontribusi masyarakat lokal serta senantiasa terjaganya peranan lingkungan. Tata cara dalam penelitian ini merupakan penelitian hukum normatif. Ada pula sumber hukum yang dipakai dalam penelitian ini merupakan materi hukum sekunder yang didapat dengan melaksanakan analisis pustaka. Analisa informasi dalam penelitian ini ialah dengan analisa dengan cara kualitatif. Bersumber pada isi ulasan terpaut pengawasan pengurusan lingkungan di aspek pertambangan bersumber pada Undang- Undang Nomor. 4 Tahun 2009 Mengenai Pertambangan Mineral Serta Batu Bara mencakup pengelolaan lingkungan hidup, reklamasi serta sesudah tambang mencakup pengelolaan serta kontrol lingkungan cocok dengan surat pengurusan lingkungan ataupun persetujuan lingkungan yang dimiliki serta sudah disetujui; penyusunan, penyembuhan, serta pemulihan tanah cocok dengan peruntukannya; penentuan serta pencairan jaminan reklamasi; pengurusan sesudah tambang; penentuan serta pencairan agunan sesudah tambang; serta pelampiasan dasar kualitas lingkungan cocok dengan determinasi peraturan perundang- undangan.
\end{abstract}

Kata Kunci: Pengawasan; Pengelolaan; Lingkungan; Pertambangan

Abstract. One of the environmental issues that affect the management of natural resources is mining activities. Based on Law No. 4 of 2009 concerning Mineral and Coal Mining began to open new horizons regarding the juridical aspects of mining management from its environmental aspects as well as being discussed about the independence of Indonesian mining. The role of the government in the formulation of environmental management supervisory policies must be optimized because natural resources have a very important role, especially in the context of increasing state revenue through clear and fair mechanisms of taxes, levies and profit sharing, and protection from ecological disasters. In line with regional autonomy, the gradual delegation of authority from the central government to regional governments in natural resource management is intended to increase the role of local communities and maintain environmental functions. The method in this research is normative legal research. The source of law used in this research is secondary legal material obtained by conducting literature review. Data analysis in this research is by qualitative analysis. Based on the contents of the discussion related to the supervision of environmental management in the mining sector based on Law no. 4 of 2009 concerning Mineral and Coal Mining covering environmental management, reclamation and post-mining including environmental management and monitoring in accordance with environmental management documents or environmental permits that are owned and have been approved; arrangement, restoration and improvement of land in accordance with its allocation; stipulation and disbursement of reclamation guarantee; post mining management; stipulation and disbursement of post-mining guarantees; and compliance with environmental quality standards in accordance with statutory provisions.

Keywords: Supervision; Management; Environment; Mining

\section{PENDAHULUAN}

Indonesia diketahui sebagai negara yang banyak dengan sumber energi alamnya. Sumber energi alam yang terbarukan (renewable) ataupun yang tidak terbarukan (non renewable) dan yang berupa modal alam (alami resources stock), semacam wilayah gerakan bengawan, situ, area lindung, pantai, dan lain- lain. ataupun dalam wujud barang semacam kusen, rotan, mineral serta gas dunia, ikan, dan lain- lain. ada menyeluruh nyaris di semua area Indonesia. Kekayaan sumber energi alam Indonesia dimengerti penguasa selaku modal bernilai dalam pengelolaan pembangunan berkepanjangan. Sebab itu, atas julukan pembangunan yang diabdikan pada pelacakan sasaran perkembangan ekonomi (economic growth development), untuk kenaikan pemasukan serta devisa negeri (state revenue), hingga eksploitasi sumberdaya alam dicoba tanpa mencermati prinsip- prinsip keseimbangan, demokratis, serta keberlanjutan guna sumberdaya alam. 
Ada pula perlindungan serta kenaikan peranan serta energi bawa lingkungan hidup, mencakup: a) memutuskan area penting nasional beroperasi lindung; b) menghindari eksploitasi ruang di area penting nasional yang berpotensi kurangi guna lindung area; c) menghalangi eksploitasi ruang di dekat area penting nasional yang berpotensi kurangi guna lindung area; d) menghalangi pengembangan infrastruktur serta alat di dalam serta di dekat area penting nasional yang bisa mengakibatkan kemajuan aktivitas budi energi; e) meningkatkan aktivitas budi energi tidak tersadar di dekat area penting nasional yang berperan bagaikan alam penunjang yang memisahkan area lindung dengan area budi energi tersadar; f) merehabilitasi guna lindung area yang menyusut dampak akibat eksploitasi ruang yang bertumbuh di dalam serta di dekat area strategis nasional. ${ }^{1}$

Permasalahan pertentangan area yang mempengaruhi pada pengurusan SDA salah satunya merupakan kegiatan pertambangan. Dampak dari kegiatan pertambangan itu tidak cuma kehilangan ekonomi namun pula memunculkan luapan sosial yang menggelisahkan. Sebutsaja melonjaknya kenaikan gesekan antara perusahan tambang dengan warga, berubahanya pola agraris warga jadi warga tambang serta yang terakhir yang senantiasa jadi materi dialog merupakan hancurnya serta tercemarnya wilayah dekat tambang. Meski terdapat upaya buat memulihkan kerusakan ataupun kontaminasi itu, tetapi sedang dirasa kurang serta tidak memegang perihal yang substantive.

Kasus yang lain yang mempengaruhi pada pengurusan SDA merupakan sedang rendahnya penjelasan akan pentingnya pengurusan SDA serta area hidup dengan cara berkelanjutan, lemahnya penguatan hukum, sedang tingginya tingkatan kontaminasi area hidup dampak belum dipatuhinya peraturan di aspek SDA serta area hidup. Misalnya, belum dipatuhinya peraturan Mengenai kotoran buangan semacam bisa diamati dari sedang tingginya kontaminasi bengawan serta laut oleh kotoran pabrik serta rumah tangga, tingginya kontaminasi hawa dampak emisi gas campakkan alat transportasi bermotor di perkotaan, dan belum optimalnya manajemen limbah bahan beresiko serta berbisa( B3). ${ }^{2}$

Bersumber pada Hukum Nomor. 4 tahun 2009 mengenai Pertambangan Mineral serta Batubara mulai membuka alam terkini mengenai pandangan yuridis mengenai pengurusan pertambangan dari pandangan lingkungannya tidak hanya pula disentuh mengenai independensi pertambangan Indonesia. Dari pandangan area UU itu mulai mengakomodir sebagian kasus area meski dengan cara prinsip area sedang banyak terlampaui terlebih jika kita becermin dengan buah pikiran Regulatory Chain yang diajukan oleh Seerden serta Heldeweg.

Kontribusi pemerintah dalam perumusan kebijaksanaan pengawasan pengurusan area harus dimaksimalkan sebab sumber energi alam amat berarti peranannya paling utama dalam bagan tingkatkan pemasukan negeri lewat metode fiskal, pungutan serta untuk hasil yang nyata serta seimbang, dan proteksi dari musibah ekologis. Searah dengan independensi wilayah, pendelegasian dengan cara berangsur- angsur wewenang penguasa pusat pada penguasa wilayah dalam pengurusan pangkal energi alam dimaksudkan buat tingkatkan andil warga lokal serta senantiasa terjaganya fungsi area.

\section{METODE \\ Jenis Penelitian}

Metode dalam riset ini merupakan: Penelitian hukum normatif. Riset hukum normatif mencakup riset kepada asas-asas hukum, penataan hukum, penyerentakan hukum dengan cara vertical serta mendatar supaya terjalin keserasian peraturan perundang-undangan tersebut berdasarkan hirarki perundang-undangan agar tidak bertentangan satu sama lain, perbandingan hukum.

\section{Spesifikasi Penelitian}

Detail riset ini memakai deskrptif analisa ialah berbentuk pemaparan dengan cara rinci serta terukur yang bisa dianalisis dengan sesuatu norma hukum yang legal.

\section{Jenis dan Sumber Hukum}

Ada pula sumber hukum yang dipakai dalam riset ini merupakan materi hukum sekunder. Materi hukum sekunder merupakan materi- materi yang didapat dari buku- buku bagaikan materi aksesoris sumber materi hukum pokok. Pangkal materi hukum ialah data- data yang didapat dengan melaksanakan amatan pustaka semacam bukubuku objektif, hasil riset serta serupanya. Materi hukum sekunder didapat dari kesusastraan, artikel di internet serta uraian pasal- pasal serta peraturan perundang- undangan.

\footnotetext{
${ }^{1}$ Buku III RPJMN 2015-2019, hlm. 30-31

${ }^{2}$ Dwi Nofi Andhiyantama, Hukum SDA, http: atau atau dwinofi. blogspot. com atau 2012 atau 01 atau hukum- sumberdaya- alam. html, hlm. 6, diakses pada bertepatan pada 25 Juli 2020.
} 


\section{Analisis Bahan Hukum}

Analisa informasi dalam penelitian ini ialah dengan analisa dengan cara kualitatif. Informasi sekunder yang didapat dianalisis dengan cara kualitatif buat menanggapi kasus dalam penelitin ini. Dalam riset ini, sehabis materi hukum terkumpul hingga materi hukum itu dianalisis buat memperoleh konklusi, wujud dalam metode analisa materi hukum merupakan Konten Analysis. Begitu juga sudah dipaparkan tadinya, kalau dalam riset normatif tidak dibutuhkan informasi alun- alun buat setelah itu dicoba analisa kepada suatu yang terdapat di balik informasi itu. Dalam analisa materi hukum tipe ini akta ataupun arsip yang dianalisis diucap dengan sebutan "bacaan". Konten analysis membuktikan pada tata cara analisa yang integratif serta dengan cara abstrak mengarah ditunjukan buat menciptakan, mengenali, memasak, serta menganalisa materi hukum buat menguasai arti, sgnifikansi, serta relevansinya. ${ }^{3}$

\section{HASIL DAN PEMBAHASAN}

\section{Arah Kebijakan Berkaitan dengan Sumber Daya Alam dan Lingkungan Hidup}

Pembangunan di aspek sumber energi alam serta area hidup pada dasarnya ialah usaha buat mengefektifkan sumber energi alam buat sebesar- besarnya kemakmuran orang dengan mencermati kelestarian fungsi serta penyeimbang area hidup, pembangunan yang berkesinambungan, kebutuhan ekonomi serta adat warga lokal, dan penyusunan ruang. Untuk menggapai tujuan serta target yang sudah diresmikan di atas, GBHN 1999 - 2004 memercayakan: ${ }^{4}$

1. Mengatur sumber energi alam serta menjaga energi dukungnya supaya berguna untuk peningkatan keselamatan orang dari angkatan ke generasi.

2. Tingkatkan eksploitasi kemampuan sumber energi alam serta area hidup dengan melaksanakan pelestarian, rehabilitasi serta pengiritan pemakaian, dengan mempraktikkan teknologi ramah area.

3. Mempraktikkan indikator- indikator yang membolehkan perlindungan kemahiran keterbaharuan dalam pengurusan sumber energi alam yang bisa diperbaharui buat menghindari kehancuran yang tidak bisa balik.

4. mengirimkan dengan cara berangsur - angsur wewenang pemerintah pusat pada pemerintah daerah dalam penerapan pengurusan sumber energi alam dengan cara hati- hati serta perawatan area hidup maka kualitas ekosistem senantiasa terpelihara, yang diatur dengan hukum.

5. Mengefektifkan sumber energi alam buat sebesar- besarnya kemakmuran orang dengan mencermati kelestarian guna serta penyeimbang area hidup, pembangunan yang berkepanjangan, kebutuhan ekonomi serta adat warga lokal dan penyusunan ruang, yang pengusahaannya diatur dengan UU.

\section{Pengelolaan Lingkungan di Indonesia}

Hukum pertambangan memiliki ikatan yang amat akrab dengan hukum area karena setiap upaya pertambangan, apakah itu berhubungan dengan pertambangan umummaupun pertambangan minyak serta gas dunia diharuskan buat menjaga kesinambungan energi bawa serta energi muat area hidup. Perihal ini, umum diucap dengan pelanggengan guna area hidup (artikel 1 nilai 5 UUPLH). ${ }^{5}$ Hukum pertambangan bagaikan salah satu aspek ilmu hukum mempunyai bermacam aspek, salah satunya di aspek lingkungan sebab objek dari kegiatan pertambangan merupakan area. Dalam perihal ini lingkungan yang diartikan merupakan baik biotik ataupun abiotik. Hukump ertambangan menaruh pandangan area bagaikan pandangan berarti sebab terdapatnya semangat serta pergantian kepada pergantian watak serta wujud dari area itu maka dibutuhkan perlakuan spesial kepada lingkungan sehingga diharapkan lingkungan yang diatur dampak kegiatan pertambangan tetap mempunyai guna serta energi area hidup yang terpelihara ataupun justru dimungkinkan bertambah.

Pengurusan lingkungan hidup merupakan usaha terstruktur buat melestarikan guna lingkungan hidup yang mencakup kebijaksanaan penyusunan, eksploitasi, pengembangan, perawatan, penyembuhan, pengawasan serta pengaturan area hidup. Dalam pengurusan area, hukum tidak hanya berperan bagaikan proteksi serta kejelasan untuk masyarakat (social control) juga sebagai media pembangunan (a tool of social engineering) dengan kedudukan bagaikan agent of development ataupun agent of change. Dalam tugasnya selaku prasarana pembangunan, hukum

\footnotetext{
${ }^{3}$ Burhan Bungin, Metodologi Riset Kualitatif: Aktualisasi Metodologi Ke arah Macam Versi Kontemporer,(Jakarta: PT. RajaGrafindo Persada, 2007).203.

4 Bappenas, Bab X Pembangunan Sumber Daya Alam dan Lingkungan Hidup, https://ww w.bappenas.go.id/files/2913/5080/2316/bab-X-pembangunan-sumber-daya-alam-dan-lingkungan-hidup.pdf, diakses pada tanggal 25 Juli 2020.

${ }^{5}$ Rangkuti, Siti Sundari, Fitur Hukum Area: Dari Ius Constitutum, Sekali Lagi, Ke Ius Constituendum, di informasikan pada Kolokium" Good Governance and Good Environmental Governance" yang diselenggarakan oleh Fakultas Hukum Universitas Airlangga bertepatan pada 28 Februari 2008 di Surabaya, hlm. 29.
} 
Eren Arif Budiman dan Ahmad Arif Zulfikar, Pengawasan Pengelolaan Lingkungan Dibidang Pertambangan Berdasarkan Undang-Undang No. 4 Tahun 2009Tentang Pertambangan Mineral dan Batu Bara

melegitimasi instrument kebijaksanaan dalam pengurusan area, ialah Dasar Kualitas area, Analisa Hal Akibat Area( AMDAL), serta perizinan area.

Bagi Siti Sundari Rangkuti penegakan hukum lingkungan berhubungan akrab dengan keahlian aparatur serta disiplin masyarakat warga kepada peraturan yang legal, yang mencakup 3 aspek hukum, ialah administratif, kejahatan serta awas, perihal ini senada dengan penafsiran penguatan hukum lingkungan yang dikemukakan oleh Biezeveld bagaikan selanjutnya: ${ }^{6}$

\section{"Environmental law enforcement can be defined as the application of sah}

governmental powers to ensure compliance with environmental regulations by means of:

a. Administrative supervision of the compliance with environmental regulations (inspection) (= mainly preventive activity);

b. Administrative measures or snctions in case of non compliance (= corrective activity)

c. Criminal investigation in case of presumed offences (= repressive activity);

d. Criminal meansures or sanction in case offeces (= repressive activity);

e. Civil action (law suit) in case of (threatening) non compliance (= preventive or corrective activity)".

Dari perihal itu, gimana kita mengambil energi antara sistem pandangan hukum lingkungan serta kegiatan pertambangan alhasil integrasi yang menyeluruh diantara sedi- segi itu menciptakan kombinasi yang idealsehingga terwujud sesuatu aturan norma yang menjurus pada cara percepatan pembangunan di aspek hukum yang efisien serta berdaya guna. Pengaturan mengenai lingkungan di bidang pertambangan merupakan salah satu rangkaian norma hukum yang berisi mekanisme hukum yang harus ditaati oleh pemrakarsa usaha dan atau kegiatan beserta penegakan hukumnya. Kedudukan aparatur negeri bagaikan pemegang wewenang aktif mempunyai andil berarti dalam cara penguatan hukum. Aparatur negeri yang berkompeten serta mempunyai integritas yang besar kepada penguatan hukum diharapkan jadi prasarana pengerak aktif yang bersenjatakan norma perundang- undangan yang legal alhasil dikemudian hari nanti sistem pengurusan area di aspek pertambangan bisa diaplikasikan dengan cara bertanggung jawab bersumber pada peraturan perundang- undangan yang legal.

Arti pertambangan bagi Hukum Nomor. 4 Tahun 2009 mengenai Pertambangan Mineral serta Batubara merupakan beberapa ataupun semua jenjang aktivitas dalam bagan riset, pengurusan danpengusahaan mineral ataupun batubara yang mencakup pelacakan biasa, investigasi, riset kelayakan, arsitektur, penambangan, pengerjaan serta pemurnian, pengangkutan serta pemasaran, dan aktivitas sesudah tambang. Pertambangan mineral serta batubara bagi PP Nomor. 23 Tahun 2009 mengenai Penerapan Aktivitas Upaya pertambangan Mineral serta Batubara digolongkan jadi 5 barang, ialah:

a. mineral radioaktif mencakup radium, thorium, uranium, monasit, serta materi galian radioaktif yang lain;

b. mineral metal mencakup litium, berilium, magnesium, potasium, kalsium, kencana, tembaga, perak, timbal, seng, timah, nikel, mangan, emas putih, bismuth, olibdenum, bauksit, airnraksa, wolfram, titanium, barit, vanadium, kromit, antimoni, kobalt, tantalum, cadmium, ngalium, nindium, yitrium, magnetit, besi, galena, alumina, niobium, zirkonium, ilmenite.

c. mineral bukan metal mencakup intan, korundum, grafit, arsen, pasir kuarsa, fluorspar, kriolit, iodin, brom, klor, sulfur, fosfat, halit, asbes, talk, mika, magnesit, yarosit, oker, fluorit, ball clay, fire clay, zeolit, kaolin.

d. batuan mencakup pumice, tras, toseki, batu gelas, pualam, perlit, tanah, sel kelamin, gioko, agato, diorit, topas, batuan gunung quarry besar, batuan galian dari busut, batuan bengawan, batuan kali, batuan bengawan memfilter tanpa pasir, pasir urug, pasir pasang, batuan berpasir natural( sirtu), materi gundukan opsi( tanah), urukan tanah setempat, tanah merah( laterit), batu gamping, onik, pasir laut, serta pasir yang tidak memiliki faktor mineral metal ataupun faktor mineral bukan metal dalam jumlah yang berarti ditinjau dari bidang ekonomi pertambangan; dan

e. batubara mencakup bitumen padat, batuan aspal, batubara, serta gambut

\section{Pengawasan Pengelolaan Pertambangan Menurut Undang-undang No. 4 tahun 2009 tentang Pertambangan Mineral dan Batubara}

Pengawasan pada dasarnya ditunjukan seluruhnya untuk menjauhi terdapatnya kemungkinan kecurangan ataupun penyimpangan atas tujuan yang hendak diraih. lewat pengawasan diharapkan bisa menolong melakukan kebijaksanaan yang sudah diresmikan buat menggapai tujuan yang sudah direncanakan dengan cara efisien serta berdaya guna. Apalagi, lewat pengawasan terwujud sesuatu kegiatan yang berhubungan akrab dengan determinasi ataupun penilaian hal sejauhmana penerapan kegiatan telah dilaksanakan. Pengawasan pula bisa mengetahui sejauhmana kebijaksanaan arahan dijalani serta hingga sejauhmana penyimpangan yang terjalin dalam penerapan

${ }^{6}$ Siti Sundari Rangkuti, Hukum Lingkungan dan Kebijaksanaan Lingkungan Nasional, Airlangga University Press, Cetakan III, 2003 hlm. 215. 
kegiatan itu. Rancangan pengawasan begitu sesungguhnya membuktikan pengawasan ialah bagian dari guna manajemen, di mana pengawasan dikira bagaikan wujud pengecekan ataupun pengontrolan dari pihak yang lebih atas pada pihak di bawahnya." Dalam ilmu manajemen, pengawasan ditempatkan bagaikan tahapan terakhir dari buat manajemen. Dari bidang administratif, pengawasan memiliki arti pula bagaikan:“ observasi atas penerapan semua aktivitas bagian badan yang ditilik buat menjamin supaya semua profesi yang lagi dilaksanakan cocok dengan konsep serta peraturan" ataupun“" sesuatu upaya supaya sesuatu profesi bisa dilaksanakan cocok dengan konsep yang sudah didetetapkan, serta dengan terdapatnya pengawasan bisa memperkecil tampaknya halangan, sebaliknya halangan yang sudah terjalin bisa lekas dikenal yang setelah itu bisa dicoba aksi perbaikannya."

Pada dasarnya pengawasan ialah suatu yang sungguh mendasar dalam kehidupan lembaga buat melindungi supaya kegiatan-kegiatan yang di praktekkan tidak menyimpang dari konsep yang sudah di tetapkan. Aktivitas badan alangkah juga kecilnya, hendak kurang berjalan cocok dengan yang di harapkan bila tanpa terdapat pengawasan. Dengan pengawasan hendak di tahu kelebihan serta kelemahan dalam penerapan manajemen. Sebutan pengawasan dalam lembaga bertabiat biasa, alhasil ada sebagian penafsiran yang bermacam- macam semacam melangsungkan pengecekan dengan cara terinci, menata kelancaran, menyamakan dengan standar, berupaya memusatkan ataupun membebankan dan pembatasannya. Tetapi pada dasarnya pengawasan.

Pengawasan memiliki tujuan supaya profesi yang di laksanakan tidak menyimpang dari konsep yang sudah di tetapkan tadinya. Begitu juga yang di ungkapkan oleh Meter. Manullang kalau tujuan penting dari pengawasan yakni mengusahakan supaya apa yang di agendakan jadi realitas. Buat bisa betul- betul merealisir tujuan penting itu, hingga pengawasan pada derajat awal bermaksud supaya penerapan profesi cocok dengan instruksi yang sudah dikeluarkan, serta buat mengenali kelemahan- kelemahan dan kesulitan- kesulitan yang di hadapi dalam penerapan konsep bersumber pada penemuan- penemuan itu bisa di ambil aksi buat membenarkannya bagus pada durasi itu atau waktuwaktu yang hendak tiba. ${ }^{7}$

Dari pernyataan di atas bisa dikenal kalau pengawasan menitikberatkan pada usaha buat membiasakan konsep yang sudah terbuat dengan aktivitas yang di laksanakan. Perihal lain yang jadi tujuan pengawasan ini merupakan menyamakan situasi yang terjalin ataupun realitas dengan apa yang sepatutnya. Dari aktivitas itu bisa di tahu kelemahan ataupun penyimpangan apa yang terjalin alhasil bisa di tahu tahap apa yang wajib di jalani berikutnya supaya kelemahan itu bisa di obati serta penyimpangan itu tidak terjalin lagi.

Guna pengawasan merupakan pengenalan bermacam aspek yang membatasi suatu aktivitas, serta pula pengumpulan tindakan koreksi yang dibutuhkan supaya tujuan badan bisa senantiasa berhasil. Bagaikan kesimpulan, guna pengawasan dibutuhkan buat membenarkan apa yang sudah direncanakan serta dikoordinasikan berjalan begitu juga mestinya ataukah tidak. Bila tidak berjalan dengan sebaiknya hingga guna pengawasan pula melaksanakan cara buat membetulkan aktivitas yang lagi berjalan supaya bisa senantiasa menggapai apa yang sudah direncanakan. Guna dari pengawasan sendiri ialah:

1. Mempertebal rasa tangung jawab seseorang yang diserahi peranan dan wewenang dalam pelaksanan pekerjan

2. karyawan supaya melakukan profesinya cocok dengan metode yang sudah ditetapkan

3. Menghindari terbentuknya kelengahan, kelemahan serta penyimpangan supaya tidak terjalin kehilangan yang tidak diinginkan

4. Membenarkan kekeliruan serta kecurangan supaya dalam penerapan pekerjan tidak hadapi halangan serta pemborosan- pemborosan

Senada dengan opini Situmorang serta Juhir, mengatakan kalau cara pengawasan pada hakekatnya dijalankan oleh administrasi serta manajemen dengan memakai 2 metode, ialah: ${ }^{8}$

1. Pengawasan secara langsung (direct control) yakni bila arahan organisasi melangsungkan sendiri pengawasan kepada aktivitas yang lagi dijalani. Pengawasan langsung ini bisa berupa:

a. inspeksi langsung,

b. on the spot observation,

c. on the spot report, yang sekalian berarti pengumpulan ketetapan on the spot pula bila dibutuhkan. Hendak namun sebab banyaknya serta kompleksnya tugas- tugas seseorang pimpinan paling utama dalam badan yang besar- seseorang arahan tidak bisa jadi bisa senantiasa melaksanakan pengawasan langsung itu. Sebab itu kerap pula beliau wajib melaksanakan pengawasan yang bertabiat tidak langsung

2. Pengawasan tidak langsung (indirect control) yakni pengawasan jarak jauh. Pengawasan ini dicoba lewat informasi yang di informasikan oleh para anak buah. Informasi itu bisa berupa :

a. tertulis,

\footnotetext{
${ }^{7}$ Manullang. 1982. Perilaku Organisasi: Konsep Dasar dan Aplikasinya. Cetakan Ke 6. Jakarta: PT.Rajawali Press, hlm. 173.

${ }^{8}$ Siagian, Sondang., P. 2008. Manajemen Sumber Daya Manusia (Edisi Pertama). Jakarta: Binapura Aksara, hlm. 139-140.
} 
b. lisan.

Kelemahan dari pada pengawasan tidak langsung itu yakni kalau sering para bawahan cuma memberi tahu keadaan yang positif saja. Dengan percakapan lain, para bawahan itu memiliki kecondongan cuma memberi tahu keadaan yang diduganya hendak mengasyikkan arahan. Sedangkan Bohari memilah berbagai metode pengawasan bagaikan selanjutnya: ${ }^{9}$

1. Pengawasan melindungi, dimaksudkan buat menghindari terbentuknya penyimpangan- penyimpangan dalam penerapan aktivitas. Pengawasan melindungi ini umumnya berupa prosedur- prosedur yang wajib ditempuh dalam penerapan aktivitas. Pengawasan melindungi ini bermaksud:

a. Menghindari terbentuknya tindakan- tindakan yang menyimpang dari dasar yang sudah ditentukan

b. Berikan prinsip untuk terselenggaranya penerapan aktivitas dengan cara berdaya guna serta efektif

c. Memastikan anjuran serta tujuan yang hendak digapai.

d. Memastikan wewenang serta tanggung jawab bagaikan lembaga sehubungan dengan kewajiban yang wajib dilaksanakan

2. Pengawasan represif, ini dilaksanakan setelah suatu aktivitas dicoba dengan membandingkan apa yang telah terangkai dengan apa yang selayaknya terangkai. Dengan pengawasan represif dimaksud untuk mengidentifikasi apakah kegiatan dan pembiayaan yang telah dicoba itu telah menduga kebijaksanaan serta pemastian yang telah ditetapkan. Pengawasan represif ini umum dicoba dalam bentuk:

a. Pengawasan dari jauh, merupakan pengawasan yang dicoba dengan metode pemeriksaan serta riset kepada surat- surat garansi jawab diiringi bukti- buktinya hal kegiatan- kegiatan yang dilaksanakan.

b. Pengawasan dari dekat, merupakan pengawasan yang dicoba di tempat aktivitas ataupun tempat penajaan administrasi

Berhubungan dengan Artikel 2 UU Nomor. 4 Tahun 2009 menyusun jika Petambangan Mineral serta Batu bara (Minerba) diatur berdasarkan:

1. Khasiat, kesamarataan serta keseimbangan

2. Keberpihakan pada kebutuhan bangsa

3. Partisipatif, kejernihan serta akuntabilitas

4. Berkepanjangan serta berwawasan area. Dasar yang terencana menggabungkan format ekonomi, area serta sosial adat dalam totalitas upaya pertambangan mineral serta batu kobaran buat menciptakan keselamatan era saat ini serta era mendatang

Pada Pasal 3 Hukum Nomor. 4 Tahun 2009 mengatur jika dalam rencana menyokong pembangunan nasional yang berkelanjutan, tujuan pengurusan mineral serta batubara merupakan:

1. Menjamin efektifitas penerapan serta pengaturan aktivitas upaya pertambangan dengan cara berdaya guna, berhadil buat serta berdaya saing;

2. Menjamin khasiat pertambangan minerba dengan cara berkepanjangan serta berwawasan lingkungan hidup;

3. Menjamin tersedianya mineral serta batubara bagaikan materi dasar serta atau ataupun sumber tenaga buat keinginan dalam negara;

4. menyokong serta menumbuh kembangkan keahlian nasional supaya lebih sanggup bersaing di tingkatan nasional, regional serta global;

5. Tingkatkan pemasukan warga lokal, wilayah serta Negeri dan menghasilkan alun- alun kegiatan yang sebesarbesarnya buat keselamatan orang.

6. Menjamin kejelasan hukum dalam penajaan aktivitas upaya pertambangan mineral serta batubara

Dengan cara biasa pembedahan pertambangan mencakup 2 perihal ialah Investigasi tercantum di dalamnya merupakan investigasi itu sendiri serta riset kelayakan serta Pembedahan Produksi yang menata mengenai arsitektur, penambangan, pengerjaan serta pemurnian, pengangkutan serta penjualalan. Dalam cara pertambangan para legislator mulai memasukkan angka serta ketentuan lingkungan sebagaisuatu cara yang tidak bisa diabaikan untuk para arsitek. Perihal ini kita bisa memandang dalam perihal sebagian perihal ialah:

1. Investigasi di mana bagaikan tahapan aktivitas upaya pertambangan, hingga dibutuhkan data hal area sosial serta area hidup.

2. Riset Kelayakan mewajibkan AMDAL dan pemograman pasca tambang.

3. Pembedahan Produksi memohon alat pengaturan akibat lingkungan pantas dengan hasil studi kelayakan.

\footnotetext{
${ }^{9}$ H. Bohari, 1990. Pengawasan Keuangan Negara, Jakarta: Rajawali Press, hlm. 25.
} 
4. Reklamasi bagaikan sesuatu aktivitas yang dicoba sejauh jenjang upaya pertambangan buat menyusun, memperbaiki, serta membenarkan mutu lingkungan serta ekosistem supaya bisa berperan kembali pantas peruntukannya.

5. Aktivitas sesudah tambang, aktivitas terencana, analitis serta bersinambung sehabis akhir beberapa ataupun semua aktivitas upaya pertambangan buat memperbaiki guna lingkungan alam serta fungsisosial bagi situasi lokal di semua kawasan penambangan

6. Dalam perihal pemberian kawasan Permisi Upaya Pertambangan (WIUP) serta Area Penahanan Negeri (WPN) energi bawa jaminan area (artikel 18 graf c serta 28 graf e) jadi ketentuan buat memperoleh izin

7. Hal agunan intensitas investigasi bayaran area dampak aktivitas ekplorasi ini jadi ketentuan buat memperoleh Permisi Upaya Pertambangan (IUP) pada pasal 39 huruf d serta Permisi Upaya Pertambangan Spesial (IUPK) pada pasal 78 huruf e. Tidak hanya itu pasal 95 mengharuskan pemegang IUP serta IUPK harus menaati batasan keterbukaan serta energi dukung lingkungan.

8. Dalam kaidah pertambangan, pasal 96 huruf melaporkan kalau pemegang IUP serta IUPK harus melakukan pengurusan serta kontrol kawasan, tercantum aktivitas reklamasi serta sesudah tambang, usaha pelestarian pangkal energi mineral serta batubara serta pengurusan sisa tambang dari sesuatu aktivitas upaya pertambangan dalam wujud padat, cair, ataupun gas hingga penuhi standar dasar kualitas lingkungan saat sebelum dilepas ke alat lingkungan.

9. Pasal 97 serta 98 mengharuskan pemegang IUP serta IUPK menjamin aplikasi standar serta dasar kualitas area cocok dengan karakter sesuatu wilayah serta melindungi kelestarian peranan serta daya bawa sumber energi air yang berhubungan cocok dengan determinasi peraturan perundang- undangan

10.Pasal 99 mengharuskan pemegang IUP serta IUPK memberikan konsep reklamasi serta konsep sesudah tambang pada dikala mengajukan permohonan IUP Pembedahan Penciptaan serta IUPK Pembedahan Penciptaan serta sediakan anggaran agunan reklamasi serta sesudah tambang

11.Buat penghentian aktivitas upaya pertambangan bisa diserahkan pada pemegang IUP serta IUPK (pasal 113 huruf c) bila situasi energi bawa area area itu tidak bisa menanggung bobot aktivitas pembedahan penciptaan sumber energi mineral serta atau ataupun batubara yang dicoba di wilayahnya

12.Pengawasan dari petugas yang berhak mencakup pengurusan area hidup, reklamasi serta sesudah tambang (pasal 141 huruf h)

13.Determinasi lain- lain melaporkan kalau tiap permasalahan yang mencuat dalam IUP serta IUPR ataupun IUPK yang berhubungan dengan akibat lingkungan dituntaskan dengan ketetapan peraturan perundang- undangan

Dengan cara khusus pengaturan hal pengawasan atas penerapan aktivitas upaya pertambangan yang berhubungan dengan area terdapat di Pasal 16 huruf h PP Nomor. 55 Tahun 2010 mengenai pembinaan serta pengawasan penajaan serta Pengurusan Upaya Pertambangan Mineral serta Batubara. Di dalam uraian lebih lanjut pada Pasal 28 PP itu diklaim kalau: Pengawasan pengurusan area hidup, reklamasi, serta sesudah tambang begitu juga diartikan dalam Pasal 16 huruf h sangat sedikit mencakup:

1. pengurusan serta kontrol lingkungan cocok dengan arsip pengurusan lingkungan ataupun permisi kawasan yang dipunyai serta sudah disetujui;

2. penyusunan, penyembuhan, serta koreksi tanah cocok dengan peruntukannya;

3. penentuan serta pencairan agunan reklamasi;

4. pengurusan pascatambang;

5. penentuan serta pencairan agunan pascatambang; dan

6. pelampiasan dasar kualitas lingkungan cocok dengan determinasi peraturan perundang- undangan

Hal pengawasan dalam pengeloaan pertambangan di Indonesia, bagi Pasal 141 hingga Penguasa dalam perihal ini Unit Tenaga serta Pangkal Energi Mineral lewat Direktorat Jenderal Pertambangan Mineral serta Batubara bisa melaksanakan pengawasan kepada penyelengaaran upaya pertambangan di wilayah serta bisa mendelegasikan wewenang pada penguasa provinsi buat melaksanakan pengawasan kepada penyelenggaran di wilayah. Pengawasan itu mencakup:

1. teknis pertambangan;

2. penjualan;

3. finansial;

4. pengerjaan informasi mineral serta batubara;

5. pelestarian pangkal energi mineral serta batubara;

6. keamanan serta kesehatan kegiatan pertambangan;

7. keamanan pembedahan pertambangan; 
8. pengurusan area hidup, reklamasi, serta sesudah tambang;

9. eksploitasi benda, pelayanan, teknologi, serta keahlian rekayasa serta rancang bangun dalam negara;

10.pengembangan daya kegiatan teknis pertambangan;

11.pengembangan serta pemberdayaan warga setempat;

12.kemampuan, pengembangan, serta aplikasi teknologi pertambangan;

13.kegiatan- kegiatan lain di aspek aktivitas upaya pertambangan yang menyangkut kebutuhan biasa;

14.pengurusan IUP ataupun IUPK; dan

15.jumlah, tipe, serta kualitas hasil upaya pertambangan

Pengawasan pada hakikatnya merupakan tertuju buat menghindari terbentuknya kelalaian serta membuktikan metode dan tujuan yang betul. Oleh karena itu lewat aplikasi prinsip koordinasi, hingga dasar pengawasan bisa maksimal dan diharapkan bisa jadi pemecahan dalam menciptakan terdapatnya penyeimbang, ialah pengurusan pertambangan yang berwawasan area, alhasil dengan begitu bisa menciptakan terselenggaranya penerapan penguatan hukum pada upaya pertambangan.

Tidak hanya pengawasan begitu juga pada penjelasan di atas, hingga pengawasan bisa dicoba dengan mengaitkan warga bagaikan pengawas ekternal begitu juga yang diatur dalam Artikel 70 UUPPLH. Pengawasan warga yang diartikan merupakan pengawasan sosial yang pastinya berlainan dengan pengawasan yang dicoba oleh administratur yang dengan cara langsung bertanggung jawab kepada terselenggaranya upaya pertambangan. Pengawasan warga pada hakikatnya merupakan berperan buat pengaturan. Lewat pengawasan warga, hingga diharapkan bisa jadi pengawasan sekalian meningkatkan pemahaman dalam diri tiap orang mengenai berartinya proteksi serta pengurusan area. Oleh karena itu, idealnya, kegiatan serupa dalam wujud kemitraan dengan warga jadi amat diperlukan dalam melaksanakan pengawasan sosial paling utama pada warga dekat yang mendapatkan akibat langsung dari dampak upaya pertambangan.

Wewenang penguasa provinsi dalam pengurusan pertambangan mineral serta batubara, di realisasikan dalam pembuatan peraturan perundang- undangan wilayah, serta pemberian Permisi Upaya Pertambangan (IUP), pembinaan, penanganan bentrokan warga serta pengawasan upaya pertambangan bagus yang berakibat area langsung karna pembedahan penciptaan yang kegiatannya pada rute area kabupaten atau kota serta atau ataupun area laut 4( empat) mil hingga dengan 12( dua belas) mil. Alhasil penginventarisasian, pelacakan serta riset dan investigasi dalam bagan mendapatkan informasi serta data mineral serta batubara cocok dengan kewenangannya. Pengembangan serta kenaikan kedudukan dan warga dalam upaya pertambangan dengan mencermati kelestarian area dan pengoordinasian perizinan serta pengawasan pemakaian materi peledak di area tambang sampai penyampaian data hasil pencatatan, pelacakan biasa, penciptaan, pemasaran dalam negara, dan ekspor serta riset dan investigasi pada Menteri serta bupati atau walikota cocok dengan kewenangannya, alhasil pembinaan serta pengawasan kepada reklamasi tanah pascatambang; serta kenaikan keahlian aparatur penguasa provinsi serta penguasa kabupaten atau kota dalam penajaan pengurusan upaya pertambangan

Dalam pengurusan pertambangan pasti terdapatnya akibat kepada area dengan independensi wilayah, penguasa membagikan wewenang pengurusan upaya pertambangan pada tubuh upaya negeri (BUMN) ataupun tubuh upaya swasta (BUMS). Perihal itu dimaksudkan dalam bagan menghasilkan sebesarbesarnya kelimpahan orang serta supaya biar warga bisa menikmati pembangunan berkepanjangan dalam area yang bagus serta segar dimana itu jadi hak dari semua bangsa Indonesia. Dalam mempunyai serta menikmati area pangkal energi alam jadi hak bangsa Indonesia begitu juga yang sudah di atur dalam pasal 28 huruf H UU Dasar Republik Indonesia Tahun 1945.

\section{SIMPULAN}

Pengawasan pengurusan lingkungan di aspek pertambangan bersumber pada UU Nomor. 4 Tahun 2009 Mengenai Pertambangan Mineral serta Batu Kobaran mencakup pengurusan area hidup, reklamasi serta sesudah tambang mencakup pengurusan serta kontrol area cocok dengan surat pengurusan lingkungan ataupun permisi kawasan yang dipunyai serta sudah disetujui; penyusunan, penyembuhan, serta koreksi tanah cocok dengan peruntukannya; penentuan serta pencairan agunan reklamasi; pengurusan sesudah tambang; penentuan serta pencairan jaminan sesudah tambang; serta pelampiasan dasar kualitas area cocok dengan tuntutan peraturan perundangundangan.

\section{DAFTAR PUSTAKA \\ Buku}

Buku III RPJMN 2015-2019.

Burhan Bungin, Metodologi Riset Kualitatif: Aktualisasi Metodologi Ke arah Macam Versi Kontemporer, (Jakarta: PT. RajaGrafindo Persada, 2007). 
Eren Arif Budiman dan Ahmad Arif Zulfikar, Pengawasan Pengelolaan Lingkungan Dibidang Pertambangan Berdasarkan Undang-Undang No. 4 Tahun 2009Tentang Pertambangan Mineral dan Batu Bara

H. Bohari, Pengawasan Finansial Negeri, Jakarta: Rajawali Press, 1990.

Manullang, Sikap Badan: Rancangan Dasar serta Aplikasinya, Edisi Ke 6. Jakarta: PT. Rajawali Press, 1982.

Marzuki, 1983, Metodologi Studi, PT Hanindita Offset, Yogyakarta.

Siagian, Sondang., P. Manajemen Pangkal Energi Orang( Versi Awal). Jakarta: Binapura Aksara, 2008.

Siti Sundari Rangkuti, Hukum Area serta Kebijaksanaan Area Nasional, Airlangga University Press, Edisi III, 2003

\section{Makalah}

Rangkuti, Siti Sundari, Fitur Hukum Area: Dari Ius Constitutum, Sekali Lagi, Ke Ius Constituendum, di informasikan pada Kolokium" Good Governance and Good Environmental Governance" yang diselenggarakan oleh Fakultas Hukum Universitas Airlangga bertepatan pada 28 Februari 2008 di Surabaya.

\section{Perundang- undangan}

Hukum Nomor. 4 tahun 2009 mengenai Pertambangan Mineral serta Batubara.

\section{Internet}

Bappenas, Ayat X Pembangunan Pangkal Energi Alam serta Area Hidup, https: atau atau ww w. bappenas. go. id atau files atau 2913 atau 5080 atau 2316 atau bab- x- pembangunan- sumber- daya- alam- dan- lingkun gan- hidup. pdf.

Dwi Nofi Andhiyantama, Hukum SDA, http: atau atau dwinofi. blogspot. com atau 2012 atau 01 atau huku msumber- daya- alam. html 